\title{
Analysis of Tourist Satisfaction Levels in Malang Regency, East Java in the New Normal Era Using Categorical Test
}

\author{
I Putu Artaya ${ }^{1}$, I Gede Arimbawa ${ }^{2}$, R. Agus Baktiono ${ }^{3}$, Made Kamisutara ${ }^{4}$ \\ Narotama University \\ ${ }_{1}^{1}$ putu.artaya@narotama.ac.id, 2gede.arimbawa@narotama.ac.id, \\ 3agus.baktiono@narotama.ac.id, ${ }^{4}$ made.kamisutara@narotama.ac.id
}

\begin{abstract}
In an effort to increase tourist visits in the new normal era to the city of Malang, East Java, the local government and the central government have made many efforts in carrying out eco-tourism activities whose main objective is to increase the number of tourist visits and the level of tourist satisfaction and local revenue in Malang Regency, East Java. Due to the increasing number of tourist visits to the city of Malang, it is necessary to make improvements in eco-tourism activities with the aim of increasing the trust and satisfaction levels of tourists who come there. Several improvements that are feasible to do so that the flow of tourist visits is getting better from year to year, are: providing lodging facilities in accordance with tourist expectations, increasing the number of tourist attraction activities, providing shopping center facilities, availability of a culinary center, organizing important events, access roads to tourist attractions, and environmental improvements in the tourist area. These seven important aspects are imperative in an effort to provide better overall service to tourists, considering the tourists who come to Malang, some come from outside the province. The data processing method used in this research is categorical test, where this test tool aims to find a map in the form of a quadrant that displays the position of tourist attractions in the city of Malang to make improvements and improvements to increase visitor satisfaction. From the results shown based on the categorical test, there are two main tourist attractions that are priority development, that is Batu Secret Zoo and Batu Night Spectacular.
\end{abstract}

Keywords: Ecotourism, tourist satisfaction, categorical test.

\section{INTRODUCTION}

The main characteristic of tourist visits is in Malang district (Anastasia, 2014) which is famous for its cold mountain air. Malang is famous for apples, a plant that only grows well in cold climates. One of the tourist attractions in Malang is called Kusuma Agrowisata, where visitors can even pick apples directly from the tree. Various tourist destinations in Malang Raya will be very suitable for those of you who want to go on vacation with your family. Malang City which is cold and has tourism potential will be very pleasant for visitors. Apart from that, there are also other fantastic destinations in Malang, especially Batu city. Visiting Malang tourist attractions is an interesting choice of attractions and recreation for children and families to do tours. If not, then going to Sengkaling or Selecta Recreational Park is the choice that attracts the most attention of visitors.

The target of increasing tourist visits, apart from being supported by the growth of various new tourist sites in various areas of Malang Regency, of course also deserves to be supported by the ability of tour guides who currently still rely on the self-taught abilities of local residents. Of course, this condition will affect tourist attractiveness and make tourists confused when they need detailed information about the locations they have visited. Especially in various historical tourist destinations. The tour guide problem cannot be ignored. They are of course required to have qualified competencies regarding various tourist destination trinkets. As has happened in various other countries, its development is supported by the life of the tourism sector (Malang Times, 2018).

The existence of regional autonomy makes each region try to explore the maximum potential of its region. Malang regency government gets income in the form of taxes from companies and from 
foreign money spent by tourists. The tourism sector is indeed an important sector in an effort to receive potential local revenue (PAD). Particularly the PAD of the Malang Regency government, one of which comes from the entrance fee tax for tourism objects in Malang Regency. Tourism development efforts have both positive and negative impacts on the community around the tourism object. The implementation of development that is oriented towards improving the welfare of the community turns out to have an impact on the surrounding environment both directly and indirectly, both in the short term and in the long term (Boris et al., 2016).

Departing from the explanation above, to support the success of tourist sites in an effort to attract tourist visits, one thing that feels important is how to create a sense of pleasure and satisfaction of visitors or tourists in supporting the activities of these tourist destinations. So it is necessary to study and analyze the driving factors that can contribute to tourist locations in Malang Regency. Because of the emergence of a good level of satisfaction, tourist visits will be increased by improving supporting factors that are generally in direct contact with tourist visit activities in an area.

\section{LITERATURE REVIEW}

\section{Understanding of Travel Destinations}

The definition of a tourist destination according to Kusuma (2012) in the complete Indonesian dictionary, a destination is defined as "a destination or a tourist destination", while according to Suwena (2017) a tourist destination is a specific area chosen by a visitor and can stay for a certain time in a location. the intended tour with a variety of purposes other than tourist visits.

\section{Definition of Tourist Destination Areas}

Tourist destination areas (Prasiasa, 2012) are places where all tourism activities can be carried out with the availability of all facilities and tourist attractions for tourists. The main elements of a tourist destination include the following:

1. A tourist object or attraction. Every tourist spot, regardless of the object being sold, must have a certain appeal in the eyes of tourists. This is a mandatory stimulant for tourist sites. Whether beach tourism, mountain tourism, religious tourism, culinary tours, shopping tours and other types of tourism. Because for tourists, an object is something that can be felt for the first time through the eye, if the object does not have an attraction and is unable to make potential visitors feel curious, then it is certain that the tourism object is incapable and has no selling value. The attraction of an object can be due to the weather, cool weather, altitude, valley, wide plain or a certain shape that can make a person or group of people feel challenged to try and come. If the initial impression is not able to create an attraction, the tourist location is not worthy of being called a place, let alone a tourist destination. Considering that there are two types of tourism objects, some are natural because of natural nuances and human creations that are deliberately made to attract visitors who are willing to come.

2. Tourism Infrastructure. In addition to the object having a high attractiveness, the second element that should not be ignored is infrastructure, which is a tool that can be used to easily and safely reach tourist sites for visitors. The availability of road access to tourist sites is an important element for visitors to reach tourist sites without having to sacrifice excessive time and energy. This is an important aspect for tourist locations in order to have the number of visitors according to expectations, of course, easy access will greatly help tourists to be willing to visit and pay as a form of economic sacrifice for the manager of tourist attractions and for the tourist destination itself. 
3. Travel facilities. Is a tool or something that is used to support tourist activities and is in the tourist area. This facility includes everything that can help visitors while enjoying tourist attractions, can be in the form of objects, goods, tools, activities, processes and the like that will make tourists optimally enjoy the atmosphere when traveling in tourist sites. Includes places of worship, cafeterias, rest areas, lodging, play areas, security guards, sanitation, parking lots, medical centers / polyclinics, ATMs, art shops, performing arts venues, and other facilities that are really needed in the area.

4. Governance of tourist attractions. Is a continuous activity related to all aspects of the tourist location, which is carried out at all times to support the safety and comfort of visitors while coming to these tourist sites. This activity may include the maintenance and maintenance of existing equipment at the tourist site so that it is always well maintained and maintained. Covers parks, trails, equipment rental, cleanliness, lighting, signs, readiness of security officers or officers on duty at tourist sites, all are maintained to create a sense of security and comfort, because visitors are willing to come and pay for one purpose, that is pleasure and satisfaction.

5. Community Environment. One aspect or other element that is also considered important is the attitude and culture of the local population when meeting tourists who visit there, of course, a culture and social conditions are needed that can support their presence with a positive perception to receive tourists with a full family attitude when tourists visit the location. travel either part time or over time. It takes a high social attitude towards the presence of tourists from local residents, this attitude and socialization will make tourists feel at home and are willing to create repeat visits at a later time. In fact, often local residents do even or certain activities that are specifically presented to tourists as an expression of the pleasure of local residents who are visited by tourists in their area.

In addition to the five elements mentioned above, a tourist destination must have five stimulants that can trigger tourist visits, which consist of:

1. Something to see. This means that before making the choice to visit, at local tourist locations or in certain places, for example abroad, of course someone must be seen and have an attractive appeal. Looking at the beginning before visiting can usually be found by means of promotion, through presenting various photos, video recordings in the form of brochures, television shows or certain events that are deliberately packaged so that potential tourists know and understand the tourist destinations offered, and then the desire to come. visit. A model like this is often used by a country when promoting its tourist destinations abroad to foreign tourists. And what is offered must be in accordance with the actual reality, because usually programs like this should not be done carelessly and can have fatal consequences if the tourist locations presented are disappointing.

2. Something to visit. This means that there is a special place, specifically for fun activities, free to do something fun without disturbing the surrounding environment, someone is free to do or celebrate or express himself when enjoying the destination tourist area without feeling disturbed or disturbed. Even tourist visits to certain areas while enjoying the atmosphere of the tour are protected by regulations made by the local government. With the aim that tourists who visit these locations do not feel disturbed by anyone's privacy. Sometimes, certain tourist locations have a special level of security so that there is no interference from people who have no interest in the tourist destination, which in turn guarantees and protects visitors' privacy. For example, security disturbances, criminal disturbances, interference from people who trade, and certain people's practices that harm tourists.

3. Something that is paid for. The meaning is that visiting a tourist destination that is offered commercially requires money to build it, of course visitors who come must be willing and willing 
to spend some money to be willing to pay for it. This is an economic mutualism in the concept of a tourist destination. Because most of the tourist locations are commercial in nature, therefore tourists can enjoy them voluntarily in making a certain amount of economic sacrifice.

4. Something you enjoy. It means that every tourist location must be able to create a sense of pleasure for every visitor, because tourist locations are not designed carelessly and are built in such a way that the main purpose is to be marketed and sold commercially. For certain areas that have tourism potential, sometimes the local government is less attentive and less interested in managing their tourism locations due to several aspects, that is limited funds, tourist locations that are too far, or too difficult to reach, or for certain reasons so that the tourism potential of the region this was deliberately ignored and did not bring economic benefits to the local government. Most of the tourist visits, indeed, the most important thing that is sought is a sense of pleasure, a sense of liking, tranquility, comfort that can provide its own entertainment for those who come. Sometimes creating such conditions is needed in addition to funds, as well as innovation, technological development, social creativity and local wisdom values.

5. Something memorable. This fifth element is indeed quite difficult to create, because to create a memorable feeling requires many aspects, one cannot rely on just one. Impressive or not depending on the tourist attraction itself and each tourist attraction has the advantage of a view or panorama that is different from one another. However, explicitly the impression of tourists' impressions can be optimized by improving service, security, comfort, responsiveness in such a way in the eyes of tourists so that all tourist needs when visiting tourist sites can be fulfilled as much as possible. Especially between one tourist attraction and another tourist attraction competing to display an attraction to attract the attention of visitors. A big challenge in the long term, if a tourism object is not able to provide an attractive dish to its tourists, in the future, the number of visitors will decrease. For example, a tourist spot in a city in the form of a zoo, if in the future the number or collection of the animals will decrease, it will make the tourist locations less attractive to visit.

\section{Tourist Satisfaction}

According to Paludi (2017), tourist satisfaction with tourist destinations is related to travel experience consisting of accommodation, weather, natural environment, social environment and others. Tourist satisfaction is closely related to the quality of the tourism products it receives. With regard to the marketing of tourism products, aspects of product quality can be observed and categorized as follows:

1. Product diversity. This concerns the physical evidence that consumers can see about the products being marketed.

2. Reliability. This concerns the consistency of the variety of products provided to consumers. That means the company must honor its promises. Reliability also concerns consumer confidence, that product providers are able and trusting to provide the promised products and services consistently, accurately and meet quality standards.

3. Responsiveness. This concerns the willingness and readiness of employees to provide services. Reaction and desire to help and provide services to consumers immediately.

4. Competence. It is focused on employee knowledge, abilities and friendliness; related to consumer belief that employees who will provide and provide services have the knowledge, skills and hospitality and have confidence in carrying out their duties. Competence also discusses the reputation of the service provider organization, the characteristics of personnel who have direct contact with consumers, the ability to maintain consumer confidentiality and security.. 
5. Empathy. This is related to personal attention to consumers, regarding consumer needs, consumer emotions, consumer complaints, and so on. Service providers must also be able to identify their customers, learn about individual consumer habits and needs, and provide personal assistance to ensure their satisfaction.

If the performance of the destination tourism product is higher than tourists' expectations, then a positive assessment can be realized. However, if the performance of the destination tourism product is below the tourists' expectations, then a negative assessment will occur. When there is a positive rating, the traveler will evaluate the experience in a positive way, and when there is a negative rating, the traveler will evaluate the experience in a negative way. The instrument used to measure the level of tourist satisfaction uses seven indicators (Suwena, 2017) as follows:

1. Lodging, which is a place to stay for tourists visiting who are around tourist sites.

2. Tourist attractions, that is everything in a tourist destination which is an attraction for people to come to visit the place..

3. Shopping centers, that is the state of shopping places that provide souvenirs and other needs of tourists who are around tourist objects.

4. Culinary, that is the variety, quality and price of food and beverages that are sold in the vicinity of tourism objects.

5. Events, that is the events that are displayed and activities that can be carried out / participated in by tourists at the tourism object location.

6. Accessibility, that is smooth or easy access to reach tourist sites.

7. Community environment, that is the condition of the environment in and around tourist objects. This includes the security of tourist locations, cleanliness, hospitality of the residents, and serenity of the atmosphere.

\section{METHOD}

\section{Location and Research Subjects}

This research activity takes five tourist objects or locations, all of which are in Malang Regency, East Java. Where, these five attractions are Eco Green Park, Museum Angkut, Batu Night Spectacular, Batu Secret Zoo, and Wendit Water Park have become quite prominent tourist destinations in the last three years. Due to the qualitative nature of this empirical research, the subjects or respondents are those who are tourist destination visitors who have visited the five tourist sites above. For the determination of the research sample, it was carried out by means of the cluster sampling method, that is determining the representatives of respondents in each tourist destination who were deemed eligible, that is knowing and understanding the five tourist locations in Malang district. So that from five tourist destinations, 84 respondents were obtained.

Statistically, in this research activity the data was taken using a questionnaire filling approach and interviewing 84 respondents who were met in five tourist areas when they visited there. The scores used according to Sugiyono (2011) are: $1=$ very important, $2=$ important, $3=$ less important, $4=$ not important, 5 = unnecessary.

\section{Data Analysis Method}

Because what is tested in this research activity is a stimulant that is able to optimize the level of satisfaction of visitors to tourist attractions and because the data is qualitative, the test form used as an analytical approach is the Categorical Test (Santoso, 2014). Where the variables used to 
indicate the level of tourist satisfaction are: Lodging, Tourist Attractions, Shopping Centers, Culinary, Event Events, Accessibility, and Community Environment. The results of the analysis are in the form of a four quadrant plane that moves counterclockwise. From these outputs, further interpretation can be made to determine the final result.

\section{RESULT}

The results of data collection at five tourist locations that have been carried out on 84 respondents can be presented as shown in the table below, as follows:

Table 1. Results of Data Collection

\begin{tabular}{|c|l|c|c|c|c|c|}
\cline { 2 - 6 } \multicolumn{2}{l|}{} & $\begin{array}{c}\text { Eco Green } \\
\text { Park } \\
(1)\end{array}$ & $\begin{array}{c}\text { Museum } \\
\text { Angkut } \\
(2)\end{array}$ & $\begin{array}{c}\text { Batu Night } \\
\text { Spectacular } \\
(3)\end{array}$ & $\begin{array}{c}\text { Batu Secret } \\
\text { Zoo } \\
(4)\end{array}$ & $\begin{array}{c}\text { Wendit } \\
\text { Water Park } \\
(5)\end{array}$ \\
\hline 1. & Lodging & 34 & 65 & 69 & 66 & 57 \\
\hline 2. & Tourist Attraction & 49 & 47 & 28 & 70 & 48 \\
\hline 3. & Shopping Center & 46 & 38 & 71 & 57 & 62 \\
\hline 4. & Culinery & 52 & 61 & 41 & 34 & 44 \\
\hline 5. & Events & 28 & 72 & 47 & 52 & 74 \\
\hline 6. & Accessibility & 37 & 49 & 50 & 49 & 51 \\
\hline 7. & $\begin{array}{l}\text { Community } \\
\text { Environment }\end{array}$ & 66 & 55 & 42 & 54 & 32 \\
\hline
\end{tabular}

Source: Results of Data Processing.

Table 2. Total Score of Tourist Satisfaction

\begin{tabular}{|l|c|}
\hline \multicolumn{1}{|c|}{ Name of Tourist Destination } & Final Score \\
\hline Museum Angkut & 387 \\
\hline Batu Secret Zoo & 382 \\
\hline Wendit Water Park & 368 \\
\hline Batu Night Spectacular & 348 \\
\hline Eco Green Park & 312 \\
\hline
\end{tabular}

Source: Results of Data Processing.

The data in table 1 above can be explained as follows, for the lodging variable in Eco Green Park, the number 34 appears, which means that from 84 respondents, 34 of them said that lodging is a very important facility ( 27 people) and important ( 7 people), then The next tourist attraction variable, there is a number 49 for the Eco Green Park column, which means that out of 84 respondents, 49 of them said that tourist attractions are very important (18 people) and important (31 people), and so on for other variables at tourist attractions.

After the data is tested using categorical data, as a whole for the five tourist destinations above, the results can be seen as shown below. 


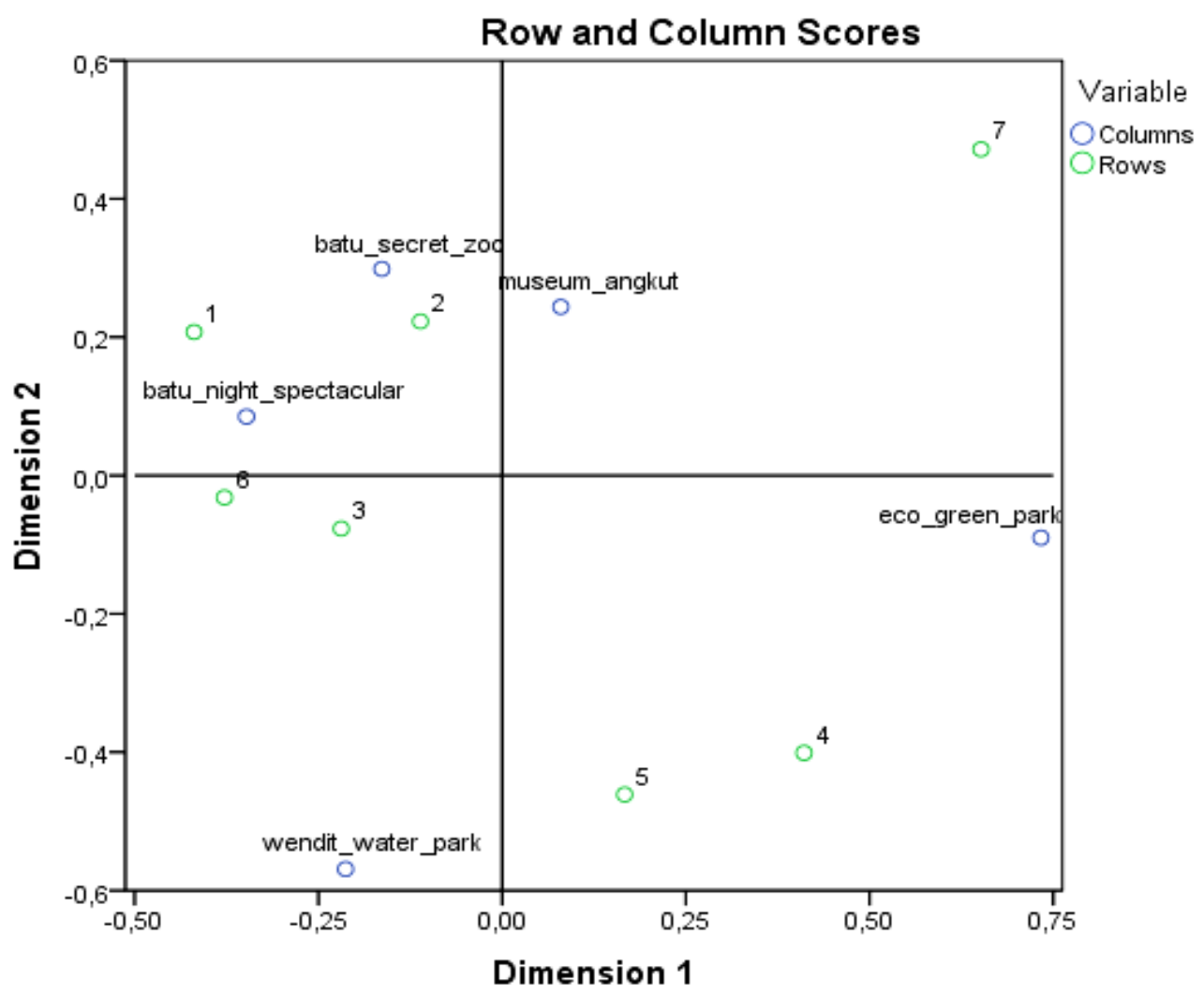

Symmetric Normalization

Source: Report of Categorical Test

Whereas in table 2 it can be seen that tourist destinations get the highest score, it indicates that visitors to these tourist destinations have the highest satisfaction compared to other tourist destinations. Of course, the tourist destination with the highest score can be used as a reference for other tourist destinations in making all forms of future improvements in an effort to improve tourist destination services in Malang district. Including improvement, maintenance of all types of facilities at all times so that visitor satisfaction does not change. Changes in visitor satisfaction can be caused by the management's lack of attention to all types of facilities available at tourist sites, this really requires serious attention. because the final goal of visitors coming to tourist sites is feeling happy, comfortable, satisfied according to the money they spend. This is an indicator that is always maintained at all times, so that tourist attractions visited by tourists can always gain trust.

\section{DISCUSSION}

If you look carefully at Figure 1 above, the explanation that can be given to review the analysis results is as follows:

1. The image is divided into four parts or quadrants, the upper right quadrant is quadrant 1 , moving left counterclockwise is quadrant 2, then the lower left is quadrant 3 and the last bottom right is quadrant 4. Each quadrant gives its own meaning to interpretation of the analyzed tourism objects. 
2. The four quadrants in Figure 1 above consist of two dimensions, where dimension 1 moves from (vertical line) point 0.00 to point 0.75 and dimension two moves from (horizontal line) point 0.00 to 0.60 . Quadrant 1 consists of three variables, that is 5,4 , and 7 . While quadrant 2 consists of variables 1,2 , and 7 .

3. We pay attention to quadrant 1 (top right) there is one tourist destination, that is the transport museum, located in dimension 1 , quadrant 1 , so that the transport museum can be optimal as a tourist destination and the level of visitor satisfaction increases, what needs to be improved optimally is variable 5 ( event events) means that the promotion is more directed at the company, the goal is that the company can come there in groups and make the transport museum their tourist destination when for example the company is holding a birthday event or gathering activity. Then variable 4 (culinary) means to support and optimize the transport museum as a tourist area, it is necessary to develop additional tourism there in the form of culinary tourism in one complex or area. While the last variable is variable 7 (environment), which means that the transport museum area can develop better, it is necessary to improve the area around the destination to the environment so that it becomes more beautiful and go green..

4. Now in quadrant 2 (top left) there are two tourist destinations, that is Batu Secret Zoo and Batu Night Spectacular. In order for these two tourist locations to be more developed, what needs to be done is to provide lodging facilities for visitors if their visit is more than one day and add tourist attraction activities in the form of shows or other activities so that the level of visitor satisfaction is more optimal.

5. Quadrant 3 (bottom left) there is one tourist destination, that is Wendit Water Park, there are two variable indications, that is variable 6 (accessibility) and variable 3 (shopping center), meaning that if there is a shopping center in the Wendit Water Park tourist location and improved access then the level of visitor satisfaction can be more optimal.

6. And the last is quadrant 4 , here there is one tourist location, that is an eco green park, and the variables indicated in this quadrant are variable 5 (event events) and variable 4 (culinary), meaning that in eco green park tourist locations, the level of satisfaction visitors can be more optimal if more events are presented that can support the attraction of visitors, for example, school children or students collectively during holidays, or other supporting activities in the form of outbound activities. Meanwhile, the culinary variables in this tourist area are inadequate and are still not well available in tourist areas. This needs further attention because tourism cannot be separated from culinary activities.

\section{CONCLUSION}

After conducting the discussion at the top of this article, what needs to be underlined as a conclusion are as follows:

Tourist destinations in Malang district do require further development and management in the long term with the aim that in the future visitor satisfaction levels will increase and have an impact on increasing tourist visits, through optimizing the level of visitor satisfaction with improvements in the areas of: lodging facilities, tourist attractions, provision shopping tourism facilities, culinary tours, introducing tourist destinations as event events by making the company a destination partner, then making improvements to easier accessibility, alternative routes during the holiday season so that there are no obstacles or congestion when tourists come there, and improving environmental rides to keep it beautiful and go green. To realize the above, it is necessary to improve in an integrated manner between one destination area and another in an integrated manner, because the tourist locations in the five places are not too far apart. 
With regard to the discussion and conclusions, the suggestions that need to be given to the Malang district government in maintaining the sustainability and management of tourist destinations, so what needs to be done in the future: As a material for consideration in efforts to improve tourist destinations in Malang Regency in the long term, the local government must be able to maintain land allotment properly so that it does not overlap with development interests that are not oriented towards land use, so that the preservation of tourism areas is maintained. Through the program, that is maintaining the designation of integrated tourist areas that maintain the preservation of tourist destinations in their entirety. Providing a more complete web-based and mobile-based information network to the wider community so that tourist destinations in Malang regency are known more quickly by the general public, and this information will stimulate tourist visits for the wider community between regions or between provinces. To facilitate access to information, management must be able to provide web-based or android-based applications in an effort to make it easier for tourists to obtain important information needed. Nowadays all types of information can be obtained online, so it is necessary to develop a more diverse and accessible means of communication online, this method is certainly part of increasing tourist satisfaction before visiting or coming to the Malang area, East Java.

Acknowledgments: We are happy to express our gratitude to the research team who have worked well together, so that all activities and actions in the research process can be completed properly. We hope that in the future, we will continue to be successful in better cooperation in other researches.

Conflicts of Interest: There are no conflicts of interest in writing this article, both among fellow writers and to external institutions as research partners.

\section{REFERENCES}

Anastasia, Melda. 2014. Sepuluh Tempat Wisata di Malang Raya Terpopuler. From http: //www.initempatwisata.com/wisata-indonesia/jawa-timur/berwisata-di-10-tempat-wisata-malangterpopuler/1279/.

Beerli A. Martin JD. 2014, Factors Influencing Destination Image. Ann. Tour. Res. 31(4). 657-681

Bories Y. A., Akhmad. Hamid, Djamhur. Topowijono. et. al. 2016. Dampak Pengembangan Pariwisata Terhadap Kehidupan Masyarakat Lokal Dikawasan Wisata. Jurnal Administrasi Bisnis. Vol.30 No. 1. pp. 69-78.

Brady, M.K. and Robertson, C.J. 2011. Searching for Consensus on The Antecedent Role of Service Quality and Satisfaction: Exploratory Crossnational Study. Journal Business Research. Vol. 51. pp. 53-60.

Kusuma, Barry. 2012. 15 Destinasi Wisata Terbaik Di Indonesia. Jakarta: PT. Elex Media Komputindo.

Malang Times. 2018. Pariwisata Kabupaten Malang Booming, Kompetensi Pemandu Wisata Terus Ditingkatkan. From https : // www. malangtimes. com/ baca / 27443/ 20180511/ 162331/ pariwisata- kabupaten- malangbooming- kompetensi-pemandu- wisata- terus- ditingkatkan/.

Paludi, Salman. 2017. Kepuasan Wisatawan. From http: //bab234.blogspot.com/2017/02/ kepuasanwisatawan.html.

Prasiasa, Dewa Putu Oka. 2012. Destinasi Pariwisata. Jakarta: Salemba Humanika.

Santoso, Singgih. 2014. Statistik Non Parametrik. Jakarta: PT. Elex Media Komputindo.

Sugiyono, 2011. Metode Penelitian Kuantitatif, Kualitatif, dan R\&D. Bandung: Alfabeta. 
Suwena, I Ketut. Widyatmaja, I Gusti Ngurah. 2017. Pengetahuan Dasar IImu Pariwisata. Denpasar: Pustaka Larasan.

(C) 2020 by the authors. Submitted for possible open access publication under the terms and conditions of the Creative Commons Attribution (CC BY SA) license (https://creativecommons.org/licenses/by-sa/3.0/). 